九州大学学術情報リポジトリ

Kyushu University Institutional Repository

\title{
Study of Critical Factors in Bulgarian Sheep
}

\section{Farms}

\section{Ivanov, Bozhidar}

Laboratory of Farm Management, Division of International Agricultural Resource Economics and Business Administration, Department of Agricultural and Resource Economics, Graduate school of Bioresource and Bioenvironmental Sciences, Kyushu University

\section{Tsuji, Masao}

Laboratory of Farm Management, Division of International Agricultural Resource Economics and Business Administration, Department of Agricultural and Resoruce Economics, Faculty of Agriculture, Kyushu University

https://doi.org/10.5109/4557

出版情報：九州大学大学院農学研究院紀要. 48 (1/2)，pp.425-442，2003-10-01. Faculty of Agriculture, Kyushu University バージョン：

権利関係 : 


\title{
Study of Critical Factors in Bulgarian Sheep Farms
}

\author{
Bozhidar IVANOV* and Masao TSUJI
}

\author{
Laboratory of Farm management, Division of International Agricultural Resource \\ Economics and Business Administration, Department of Agricultural Economics, \\ Faculty of Agricultur, Kyushu University, Fukuoka 812-8581, Japan \\ (Received June 30, 2003 and accepted July 15, 2003)
}

\begin{abstract}
In Bulgarian economy now runs the free market economic principles. It means that all of rational sheep farmers strive to get more income. The research will be concentrated to study "critical factors" that determine profitable or losing profiles of different type (mountainous and plain) and size (nominal, small, medium, large) farms. Along with favorable increasing of sheep number within particular farms is important to be achieved production growth. The current levels of production are poor thus sheep farmers must rise it by adoption of higher fecundity breeds and rams and improved husbandry. Nowadays, throughout country the pastureland amounts to $1,5-1,6$ million ha. About $75-80 \%$ is located on hills and steep slope places intrinsic for sheep grazing. Therefore, farmers in mountainous regions should exploit the possibilities for enhancing sheep number while farmers from plain regions to try to transform barren land there unto pasture area.
\end{abstract}

\section{INTRODUCTION}

Regarding to sheep, it is important enterprise for national economy. For long time our country has positioned the primary spots in worldwide and first spot in Europe by number of the sheep on 100 ha utilized area likewise produced wool per capita. Dramatic changes in farm structures appeared after the Communist Party won the State power. Through Co-operative Law enacted in 1945, the holders were forced to join with their land, livestock and other assets into Labor Cooperative Agricultural Farms (TKZS). The collectivization process was completed by 1958 likewise about 3200 cooperatives were established. After 1989 in the structure of sheep production appeared significant changes. Nowadays, about $97 \%$ of sheep are kept in private farms, of which $61 \%$ are householders who keep between 1-5 heads. Besides $27 \%$ of all farmers have $6-10$ sheep, while $88 \%$ of sheep farmers keep up to 10 sheep. On the other hand, less than $1 \%$ of farmers keep over $50-100$ heads. Over last 10 years the sheep number shrank with 5843 $596(71,9 \%)$ as in 2001 the sheep numbered 2281406.

In Bulgarian economy now runs the free market economic principles. It means that all of rational sheep farmers strive to get more income. Besides, farmers face such "critical factors" that at great extent predetermine state of those farms. Study of these factors will allow to be found out reasons and specifics which exist in this enterprise as well as to be outline differences between various size and type farms.

* Laboratory of Farm Management, Division of International Agricultural Resource Economics and Business Administration, Department of Agricultural and Resource Economics, Graduate school of Bioresouce and Bioenvironmental Sciences, Kyushu University, Fukuoka 812-8581, Japan.

${ }^{+}$Corresponding author (E-mail: chois@agr.kyushu-u.ac.jp) 


\section{OUTLINE OF THE RESEARCH}

\section{Theoretical premise}

Main economic reforms, institutions and legal framework shall be described as well as the basic hypothesis will be that effectiveness of a factor depends on the state of other determinants with which it is interfaced. It means that focusing only upon internal problems of sheep enterprise will be unreliable, therefore the analysis of external factors is necessitated. Developing of vital family sheep is related with competition. The competition drives the rational behavior of the farms with market requirements, so that the ill-run farms are punished and well-operated farms are rewarded. Regarding to Bulgarian sheep farming pattern where there isn't obvious dispersion between profit capabilities of particular farms, allow to conclude that prevailing problem for Bulgarian sheep farming is set outside and instituting a precise mechanism would propel up this sector.

Research of external issues needs to discern some focal points. The chief external issue, which influence on the sheep farming, is the price level. For sheep farmers are important the price of staple sheep products-milk, meat and wool. The price of these products is derived from demand of it. The farmers must seek possibilities bigger part of marketing margin to remain for them. Generally, the customer market especially of sheep milk products (mostly various kinds of cheese) is shrugged but great number of dairy companies work with high production costs as well as don't address with their faults and manipulate only the final and purchase prices without earnest aftermath for themselves.

The research of internal issues shall be drawn to clarify primary problems of sheep farming. From first sight, we can denote heterogeneity in conditions under which operate particular sheep farms. Mostly in some part of plain area the farmers don't have problems with milk sale but in bigger part of the country, dominantly mountainous regions (because of dotting character of residential places and worse infrastructure) the sheep milk is purchased poorly. That is why, the sheep farmers in latter regions must find organizational forms to process own production or to make contacts with dairy enterprises. In this case, the State must support such farm initiation as well as to protrude those firms that parasite on sheep farmers' back. The another grave issue for sheep farmers is to stop their ambiguous being and to grow up to real farms. Their intention must be maximizing of their potential not self-sufficiency. Besides, the farmers have to solve management issues belong to their tasks. For example, these are issues connected to optimal size of the entities, farm structure (mix or single enterprise), breeding management, feeding and shepherding issues, etc. In addition, the most of farms must be enlarged in order to be avoided considerable fixed cost (mostly low loading of the labor) thereby the common commoditization of this production would mark up and utilization of available low price land would rise as well.

\section{Methodology}

The research covers the sheep production in Bulgaria. Regarding to this purpose all farms within there is sheep enterprise, are object of the analysis. The farm classification is done by two criteria - territorial (mountainous, flat) and size (nominal, small, medium, large-scale farms)

1. Territorial-mountainous type - mountainous regions of Bulgaria are more proper for 
sheep development but major share of sheep farms in these regions are small concerning their size. According to statistical data the sheep keeping in these areas are between $40-45 \%$ of all sheep herd, while farm number is between $50-55 \%$ out of all sheep farms. As mountainous will be defined all farms with attitude over $700 \mathrm{~m}$. In field-study sample the fraction of mountainous farms is about $50 \%$ of all surveyed farms

2. Territorial-plain type - the plain regions are more genial for crop farm but on account of good feed security the sheep number amounts to $55-60 \%$ of all sheep herd as only $45-50 \%$ of sheep farms are located in these areas. It indicates that concentration in these regions is higher than mountainous ones. The fraction of these farms in field survey is about $50 \%$ of all covered farms in approximately same proportions with mountainous units

The another criteria of farm classification is the size of sheep farms. Regarding to this criteria the sheep farms are qualified to nominal, small, medium, large-scale farms, which pertains only to sheep enterprise in those farms. For example, a particular farm can have large-scale crop enterprise (tens hectares of land) or large-cattle production but if the sheep enterprise is small by sheep farming criteria this farm will be considered as small sheep enterprise farm

3. The nominal sheep farms are determined as farms that dispose with up to 20 sheep (dairy and sheep in fertility stage). The units under this class possess mutual features (high percentage of self-sufficiency, dominantly old-aged owners, widespread consigning their herds for shepherding to other farmers, etc)

4. Small-scale class - this class encompasses the entities with 21-50 sheep. This class is defined as small because the incomes obtained by it are insufficient and farmers can not count only on them. Besides, between farms there are many similarities

5. Medium-scale class - to determine a farm as such is necessary the sheep flock there to be between 51-100. Within this class there are physical persons and commercial farms as well. These farms can not be determined as large farms because conditions in Bulgaria let to have bigger ones than these

6. Large-scale class - over 101 heads. According to statistical data about sheep, can be ascertained that most of sheep farms over 101 heads gravitate around this number. That is why, isn't precisely the threshold of this class to be fixed upper

\section{Background of sheep enterprise development}

When the transformation of the former political and economic system started in 1989 the fundamental reforms of the agrarian structures was on agenda. Development toward market-oriented farming based on private ownership was undertaken (Bashev 2000). During this time the keen collapse occurred in sheep enterprise. Liquidation of ancient Labor Cooperative Agricultural Farms (TKZS) was connected with vast off of sheep and their apportion unto cooperation members as stake. Meanwhile, the most considerable decreasing in livestock number happened in the sheep enterprise accounted for $349 \%$, while within other enterprises it was about $380 \%$ pig, $242 \%$ poultry, $246 \%$ cattle, etc. Regarding to above facts, it must be pointed out the concomitant problems with breeding activity. These problems have aggravated breeding achievements seeing that only $2 \%$ of all sheep were controlled by Agency for Breeding and Reproduction. Besides, the emer- 
gent private sheep farmers didn't manage to retain whole sheep population and they gradually divested by either slaughtering or selling to firms engaged in animal export. Through a decision from 1992 was permitted the export of thoroughbred sheep in consequence of which vanished some of the most worthsome herds in Bulgaria (for example in Sadievo and Veselinovo), that were created by large funds and efforts of many scientists. From first sight is visible that 1992-1994 is break-even time for sheep production. It is characterized with inverting the proportion between public and private sheep husbandry and inception of great downward in this production. During first several years in transition period, the sheep farmers merited from relatively high prices and regular purchasing of various sheep products.

Table 1. State of sheep enterprise under in transition span

\begin{tabular}{llrlrrrrrr}
\hline & & 1988 & 1990 & 1992 & 1994 & 1995 & 1996 & 1997 & 1998 \\
\hline Total sheep number & thousands & 8886 & 8130 & 6703 & 3763 & 3398 & 3383 & 3020 & 2848 \\
Of which in public sector & thousands & 6073 & 5521 & 3443 & 470 & 261 & 40 & 33 & 27 \\
$\begin{array}{l}\text { Of which in private sector } \\
\text { Total milk production }\end{array}$ & thousands & 2013 & 2549 & 3260 & 3293 & 3137 & 3343 & 2987 & 2821 \\
$\begin{array}{l}\text { Total meat production } \\
\text { (in carcass) }\end{array}$ & tons & 90523 & 72969 & 83515 & 56446 & 49495 & 59643 & 50449 & 53010 \\
Total wool production & tons & 30654 & 27811 & 19109 & 11518 & 8790 & 9211 & 7386 & 7937 \\
\hline
\end{tabular}

Source: National Statistical Institute

It was due to still existence of Bulgarian foreign markets of sheep products over first years of this span and State abolishment as an agent whom has gripped the extra value in each product. Moreover, at beginning of transition period, from Bulgaria was exported in 1993 (693 000), 1994 (936 000), 1995 (263 000) sheep in live as contrarily in 1998 the export was hardly 2 thousand. Meantime, generated by new private farmers incomes from sheep production were imbibed by great inflation flared in the same time. Financial instability in that time dubbed the sheep farming development and dictated the behavior of owners. The internal obstacles for sheep husbandry were delineated as disability of farmers to set up a high-productive and good equipped farming as well as to keep suitable breeding process in them. Moreover the farmers were not ensured with necessary machines for feed procurement thus the direct costs for sheep keeping were enhanced. Besides, the unpleasant market state in terms of wool production impelled many farmers to betake in dairy sheep.

\section{NATURE OF INTERNAL FACTORS IN SHEEP FARMS}

\section{Size of sheep farms}

An optimum size of sheep farming is considered to be the size, which yields the greatest return or surplus to the inputs considered as fixed. Principally, farm size is related to income in two ways: (1) the amount of income is dependent of size of farm and hence the amount of capital. Even where there are no cost advantages or disadvantages 
for farms of various size, small farms will have, under usual price relationships lower incomes than large farms. (2) The amount of income relative to the quantity of resources used depended on the return to scale of farms of different size. Nowadays, the sheep production isn't able to acclaim with a good size structure which to guarantee well-being of those farms. At last years, the sheep number in Bulgaria has reached to its critical point about 2 million heads kept within about 251 thousands units. From size point of view is impossible to speak for a prospective and lucrative enterprise. These super-small sheep units raise sheep mostly for self-sufficiency and can't accumulate adequate income. Regarding to higher labor cost in sheep enterprise than other ones, the under optimal size farms incur bigger keeping costs and don't have possibility for bilateral dealing in Bulgarian strong differential dealing model. Not professional pattern of Bulgarian sheep farming model is the foremost feature of it.

Table 2. Structure of sheep production in present time

\begin{tabular}{|c|c|c|c|c|c|c|c|c|c|}
\hline \multirow{2}{*}{ 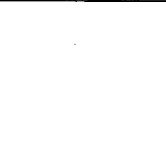 } & \multicolumn{3}{|c|}{ Professional farms } & \multicolumn{3}{|c|}{ Not professional farms } & \multicolumn{3}{|c|}{ All sheep farms in Bulgaria } \\
\hline & $\begin{array}{c}\text { Sheep } \\
\text { number }\end{array}$ & $\begin{array}{c}\text { Farm } \\
\text { number }\end{array}$ & $\begin{array}{l}\text { Average } \\
\text { sheep } \\
\text { number }\end{array}$ & $\begin{array}{c}\text { Sheep } \\
\text { number }\end{array}$ & $\begin{array}{c}\text { Farm } \\
\text { number }\end{array}$ & $\begin{array}{l}\text { Average } \\
\text { sheep } \\
\text { number }\end{array}$ & $\begin{array}{c}\text { Sheep } \\
\text { number }\end{array}$ & $\begin{array}{c}\text { Farm } \\
\text { number }\end{array}$ & $\begin{array}{c}\text { Average } \\
\text { sheep } \\
\text { number }\end{array}$ \\
\hline During 2000 . & 165000 & 2310 & 71.5 & 1288000 & 239750 & 5.4 & 1452000 & 242060 & 6 \\
\hline During 2001 & 247000 & 4420 & 55.3 & 1324000 & 246700 & 5.4 & 1571000 & 251120 & 6.3 \\
\hline
\end{tabular}

Source: Agrostatistical department, 2002

Only $1.8 \%$ of all farms reckoning themselves as entities deal with sheep farming as main occupation. For instance, this structure in sheep enterprise is the most adverse among all livestock, which underlines deep problems of it. By same point of view, the farms with more than 50 pigs represent $1.6 \%$ of all swine farms but they keep $44.5 \%$ of all pigs, while $1.8 \%$ of large sheep farms keep only $15.7 \%$. The table below shows that internal structure of sheep isn't distorted. Almost all farms try to sustain a stable ratio between fertility and no fertility sheep at proportion 4:1.

Table 3. Internal structure of sheep enterprise by classes

\begin{tabular}{lcccccr}
\hline Farm classes & $\begin{array}{c}\text { \% out of all } \\
\text { sheep farms } \\
\text { (secondary data) }\end{array}$ & $\begin{array}{c}\text { Average } \\
\text { sheep } \\
\text { number }\end{array}$ & $\begin{array}{c}\text { Average } \\
\text { number of } \\
\text { hoggets }\end{array}$ & $\begin{array}{c}\text { Average no } \\
\text { fertility sheep } \\
\text { number }\end{array}$ & $\begin{array}{c}\text { Average } \\
\text { ram } \\
\text { number }\end{array}$ & $\begin{array}{c}\text { Average } \\
\text { number } \\
\text { of ewes }\end{array}$ \\
\hline Large scale farms & $0.4 \%$ & 217.6 & 35.6 & 33 & 4.4 & 144.6 \\
Medium scale farms & $0.6 \%$ & 63.8 & 8.8 & 5 & 2.7 & 47.3 \\
Small scale farms & $9 \%$ & 30.9 & 4.2 & 3.7 & 2.1 & 20.5 \\
Nominal sheep farms & $90 \%$ & 9.8 & 1.4 & 1.1 & 0.5 & 6.8 \\
\hline
\end{tabular}

Source: Primary data, 2002

The high uncertainty in sheep enterprise entails wavering behavior seeing variation in 
ram number in particular classes. The nominal and small sheep farms raise relatively higher share of rams about 1 ram to 10-12 dairy sheep, while within medium and large this ratio is much more appropriate which also boost their scale effectiveness.

\section{Production system}

Livestock production systems are considered as a subset of the farming system. On the other hand, sheep enterprise belongs to the livestock system. In consequence of increasing in livestock products demand, intensive production system become more prevalent. The sheep production system can be classified to specialized sheep production and mixed sheep production (dominantly livestock character or dominantly crop one). Most of researches prove that economic performance of mixed farming system is better than that of specialized farming system. Differences in economic performance originate from agronomic-technical, organizational and institutional differences.

The specialized sheep farms in Bulgaria represent hardly $1 \%$ of all farms. The specialized sheep farms have ability to adopt industrial methods in sheep husbandry. But in account of higher market uncertainty in sheep production than other sectors of agriculture the specialized sheep units don't play ultimate role in this production. Nevertheless, in fulfilled survey' 2002 was ascertained operating of small sheep farms with high fraction of inputs. These farms apply intensive raising of lambs (sucking duration between 70-90 days, targeting higher maturity in the flock through culling activity and autumn sale of fertility sheep instead of spring sale of lambs). The another kind of sheep production system-the mixed sheep farms represent $99 \%$ of all sheep farms as well as they keep $88.6 \%$ of all sheep. If sheep farmers can not resort to external inputs, the integration of different productions stands for their main avenue for intensification. Mixed farming thus constitute the basis for modern agriculture.

Table 4. General structure of sheep farms by classes

\begin{tabular}{|c|c|c|c|c|c|c|c|c|}
\hline \multirow{2}{*}{$\begin{array}{l}\text { Farm } \\
\text { classes }\end{array}$} & \multicolumn{4}{|c|}{ Average number of livestock/number } & \multicolumn{4}{|c|}{ Average size or crop productions/ha } \\
\hline & Cattle & Swine & Poultry & Equine & Cereal & $\begin{array}{c}\text { Industrial } \\
\text { crops }\end{array}$ & Vegetables & $\begin{array}{l}\text { Meadow } \\
\text { and Lucerne }\end{array}$ \\
\hline Large scale farms & 76 & 226 & 5.544 & 4 & 207.2 & 6.6 & 1.6 & 17.3 \\
\hline Medium scale farms & 7 & 26 & $\sim$ not & $\sim$ not & 3.6 & 2.8 & $\sim$ not & 4.5 \\
\hline Small scale farms & 3 & 6 & 8 & 0.6 & 2 & 0.04 & 0.2 & 2.2 \\
\hline Nominal sheep farms & 1.7 & 0.5 & 5.5 & 0.7 & 0.2 & 0.1 & 0.08 & 2.4 \\
\hline
\end{tabular}

Source: Survey data, 2002

From data above is obviously the great difference between large-scale farms and rest of farm classes. These farms in bigger part are commercial entities that dispose with various stage production activities (agricultural production, processing and trade) which delineate them as vertical integrated entities. For them, sheep enterprise is not priority and chief purpose for their engagement in that production is maximization of their aggregate firm profit. Even if they don't dispose with own processing opportunities for sheep products they keep on to have good position to achieve bilateral contract with such 
enterprises on the better price than other smaller farms. The picture, which pertains to other classes is fairly more different. Between farms of these 3 classes there are some main similarities. Usually, these entities are occupied in maximum 2,3 divergent enterprises as well as they depend stronger than large-scale farms from other participants in production chain. The farmers of those classes mostly dovetail sheep production with other livestock (cattle and pigs) as it is rarely to be dovetailed sheep enterprise along with crop productions.

\section{Investment}

In the nonagricultural business the final profit value is often expressed as a percent return on investment. The investment is in direct relation to the capital of the particular farm. The purpose of investment is to increase resource efficiency, or incomes and level of living. The investment in sheep husbandry can be traversed regarding need for increasing intensification of it. In Bulgarian conditions under scarce capital of sheep farmers, low prices of sheep products and volatile demand of these products is necessary, farmers to use more precisely the opportunity cost principal by comparing the returns from adoption of new production technologies and returns bound to increase productivity of sheep. The major indicator of investment is return on investment. In ROI calculation shall be used theoretical variant of operating income and total investment under other things equal. A priori assumption is that the most worthwhile investment leads to increasing in productivity. Calculation of feasible gross value of various sheep products will be done conceding that purchasing of those commodities is perfect.

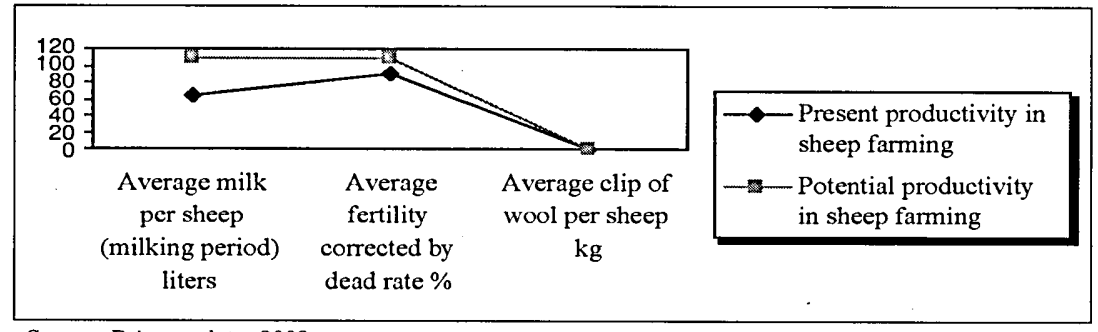

Source: Primary data, 2002

Fig. 1. Average changes on investment for productivity increasing

Table 5. Calculation of present and potential operating income

\begin{tabular}{lcccccccc}
\hline & \multicolumn{3}{c}{ Present productivity } & & \multicolumn{3}{c}{ Potential productivity } \\
\cline { 2 - 3 } & Quantity & $\begin{array}{c}\text { Price } \$ \\
\text { per kg }\end{array}$ & $\begin{array}{c}\text { Total operating } \\
\text { income } \$\end{array}$ & & Quantity & $\begin{array}{c}\text { Price } \$ \\
\text { per kg }\end{array}$ & $\begin{array}{c}\text { Total operating } \\
\text { income } \$\end{array}$ \\
\hline $\begin{array}{c}\text { Average milk per } \\
\text { sheep/liter }\end{array}$ & 65 & 0.33 & 21.45 & & 110 & 0.33 & 36.3 \\
$\begin{array}{c}\text { Average weight of } \\
\text { lambs/kg. in live } \\
\text { Average clip of wool } \\
\text { per sheep/kg }\end{array}$ & 22.5 & 1.50 & 33.75 & & 27.5 & 1.50 & 41.25 \\
\hline
\end{tabular}

Source: Primary data, 2000 and NSI, 2001 
According to NSI the produced sheep milk during 2000 represented $5.7 \%$ out of total milk production in Bulgaria but only $15 \%$ of these quantity is purchased by manufacturers. The average purchasing prices of sheep milk recently varies about $\$ 0.33$ per liter. The matter with productivity is basic since the recent dead rate of offspring and lambs is about $15-20 \%$. In most of cases the offspring are born but they aren't preserved. As for wool production the average clip of wool per sheep will have a permanent trend because of altered market reality and hard recovering of textile industry.

The analysis of investment expediency will be made collating the changes after investment and in present situation. The prices of particular sheep commodities are based on average purchasing prices recently. The potential productivity is planned taking into account not only pure adoption of improved breeds but level of technological state is also regarded. For instance the milk yield of eligible sheep breeds can tally up to 160-170 l. per lactation cycle likewise it requires much cares and congruent technology.

Table 6. Calculation of feasible investment cost for breed improving

\begin{tabular}{ccccccc}
\hline $\begin{array}{c}\text { Indispensable } \\
\text { rams/number }\end{array}$ & $\begin{array}{c}\text { Price per } \\
\text { head } \$\end{array}$ & $\begin{array}{c}\text { Total } \\
\text { expenditures } \\
\text { for rams } \$\end{array}$ & $\begin{array}{c}\text { Indispensable } \\
\text { breeding } \\
\text { sheep/number }\end{array}$ & $\begin{array}{c}\text { Price per } \\
\text { head } \$\end{array}$ & $\begin{array}{c}\text { Total } \\
\text { expenditures } \\
\text { for sheep } \$\end{array}$ & $\begin{array}{c}\text { Total } \\
\text { investment } \$\end{array}$ \\
\hline 1 & $\sim 200$ & $\sim 200$ & 8 & $\sim 70$ & $\sim 560$ & $\sim 760$ \\
\hline
\end{tabular}

Source: Estimation

The investment which are necessary to implement the potential productivity will be outlined by embedding rams and breeding sheep with improved qualities. The indispensable agenda for implementation of higher purposes can be demonstrated by one model of 40 sheep herd. The potential productivity of such herd demands embedding of 1 thoroughbred ram and $20 \%$ improved breeding sheep. It needs to be noticed that expenditures are irreversible while the risks under new conditions are increment. These are risks bound to qualities of ram and sheep, their existence, genetic appearance, etc.

Total operating income per year $\$ 372 \quad$ Total amount of investment $\$ 760$ Total operating income over 3 years $\$ 1116$

$$
\mathrm{ROI}=\text { operating income/ total investment }=\$ 1162 / \$ 720=153 \%
$$

The ROI was calculated over 3 years period because optimal using of ram and gradual embedding of sheep will take about 3 years. Aftermath of this adoption will be spilt out since by this embedding will be ultimate improved the genetic lines within herds. This ROI isn't overestimated, as the potential productivity is in compliance with environment factors not only biological ones. The condition of other things equal claims that farmers will not have problems with selling of their productions as well as they will be able to catch those prices, which unfortunately isn't mutual for major of them. Therefore these investment are rational for bigger farms that have a certain market of their products. 


\section{ENVIRONMENT CHARACTERISTICS IN PRESENT TIME}

\section{Conflict of interests}

This chapter will be traversed in the sight of some assumption of New Institutional Economics and its main scholars. The significant contribution of this new stream in economic theory space is spotlighted of behavior aspects within economic relations. For them such prepositions are behavioral ones of bounded rationality and opportunism. The Williamson state of "opportunism" goes beyond the assumption of self-seeking which prevails in conventional microeconomics (Williamson, 1983). Opportunism involves "self-seeking with guile" (Williamson, 1983) but it is scarcely limited to more blatant forms, such as lying, stealing, and cheating. Opportunism often involves subtle forms of deceit. Bounded rationality affects the realm of human behavior that is intendedly rational, but only limited so. Simon believes that "human behavior is, if not wholly rational, at least in good part intendedly so" (1976). If bounded rationality and opportunism are assumed, then transaction costs will be affected by environmental factors as asset specificity, uncertainty and frequency. Asset specificity occurs when an investment is made for specific rather than a general purpose. When uncertainty increases, the framework within which transactions take part can become crucial if asset-specific investments are at stake. As the frequency of transactions increases it becomes more likely that the parties will unify and that they will become vertically integrated within a single firm.

The sheep farming throughout world, in particularly in Bulgaria possesses these features. The specificity comes from high price dependence of demand of sheep products. Altogether, the sheep products compete with similar products within a homogeneous market, where the most might factor determines the customer choice are price levels. The above data prove higher sensitiveness of the purchased sheep milk in comparison with milk-all. While in central-planning span characterized with decrement uncertainty percent of purchased sheep milk fluctuated in same levels with purchased milk-all in new economic conditions (increment uncertainty) the proportions between

Table 7. Intersectional analysis about purchasing of milk-all and sheep milk

\begin{tabular}{crrrrrrrr}
\hline $\begin{array}{c}\text { Quantities and } \\
\text { percents }\end{array}$ & 1980 & 1988 & 1990 & 1994 & 1996 & 1998 & 2000 & $2001^{1}$ \\
\hline $\begin{array}{c}\text { Total produced milk } \\
\text { (thousand liter) }\end{array}$ & 2151341 & 2493475 & 2384922 & 1420497 & 1383543 & 1589016 & 1655518 & 985960 \\
$\begin{array}{c}\text { Purchased milk-all } \\
\text { (thousand. liter) }\end{array}$ & 1663991 & 2040277 & 1969006 & 847460 & 864383 & 409906 & 185432 & 336347 \\
$\begin{array}{c}\text { \% of purchased milk-all } \\
\text { from total produced }\end{array}$ & 77.3 & 81.8 & 82.6 & 59.7 & 62.5 & 25.8 & 10.9 & 34.1 \\
$\begin{array}{c}\text { Total produced sheep } \\
\text { milk (thousands) }\end{array}$ & 289060 & 284259 & 262911 & 129430 & 110318 & 105965 & 93746 & 69614 \\
$\begin{array}{c}\text { Purchased sheep milk } \\
\text { (thousand liters) }\end{array}$ & 209879 & 239109 & 223790 & 56677 & 29071 & 13513 & 12411 & 22154 \\
$\begin{array}{c}\text { \% of purchased sheep } \\
\text { to total produced milk }\end{array}$ & 70.7 & 81.3 & 85.1 & 43.8 & 26.4 & 12.8 & 13.2 & 31.8 \\
\hline
\end{tabular}

Source: National Statistical Institute, 2001 and Agro-statistical Department 
purchased milk-all and purchased sheep milk are distorted.

The above data prove higher sensitiveness of the purchased sheep milk in comparison with milk-all. While in central-planning span characterized with decrement uncertainty percent of purchased sheep milk fluctuated in same levels with purchased milk-all in new economic conditions (increment uncertainty) the proportions between purchased milk-all and purchased sheep milk are distorted. Nevertheless, optimistic fact is figures in 2001, claiming growth in purchased sheep milk, which is due to great extent of falling of total production of sheep milk. Indeed, great part of tumble in production from sheep is due to changes in economic system and inability of sheep production to keep its position in competitive market (domestic and international). But the competition between farmers and manufacturers and middlemen mutates in overt rival where each side is eager to grasp more from marginal (surplus) value of particular products. Throughout in transition period have been occurred cases of apparent deceit as manufacturers have stipulated especially in milk purchasing with producers but in the end, they either didn't pay stipulated price in same size or outright vanished repudiating any commitments. It occurred in consequence of great number of dairy and commercial firms that arose, that do not have necessitated capital and production capacity to grow and to create demand of their production. Thence this conflict of interest between farmers and other sides in market chain arises as through preventing illicit acts of stronger side and by law enforcement will be ceased a harming sheep enterprise practice. As I have noted, the inability of state to develop effective, low-cost enforcement is the most important source of contemporary stagnation. One of coping way with conflict of interests is the cooperation, vertical integration and by entering of solid, good reputed companies mostly in dairy enterprise. Currently, such forms exist but they cover minor part of territory as well as around them are concentrated the main units of sheep husbandry with greater part of bigger sheep flocks (over 100 sheep). Under these conditions cheating, shirking, opportunism, all problems of business relations are limited or indeed absent. But such trend of organizational development may transmute unto syndicalism and collusive activities therefore the state must pay attention for it and for competition level.

\section{Distortion of market optimality}

Coase (1988) argues that "analysis of the market deals with the determination of prices, but discussion of the market itself has entirely disappeared". The organization "market" consists of a set of institutional rules (an institution) plus the people who create and apply such rules to trade in type and goods. In the case of perfect market with zero information and enforcement costs the distortion of optimal market equilibrium would not be a fact. Therefore, the distortion as concept is claimed by welfare economics. This is the general term for normative analysis of economic systems: for the study of what is right and what is wrong about economy's functioning. The distortion of optimal allocation of resources is enmeshed with market failures ensue from imperfect competition and externalities.

The such matters in sheep farming can be found in inability of competitive forces to establish worthwhile market conditions for some of sheep products (e.g. milk and wool) as well as in skewing of bargaining relationship between farmers and middlemen. Hence economic stronger group can rig prices on self-merit, incurring weaker in terms of bar- 
Table 8. Relation between sheep farmers and dairy enterprises

\begin{tabular}{cccccccc}
\hline Relation & Producers & Total milk & Sheep milk & \multicolumn{3}{c}{ Relation between producers and enterprises } \\
\cline { 6 - 8 } $\begin{array}{c}\text { between } \\
\text { phoducers and } \\
\text { enterprises }\end{array}$ & $\begin{array}{c}\text { is purchased } \\
\text { directly }\end{array}$ & $\begin{array}{c}\text { purchased } \\
\text { directly } \\
\text { (t) }\end{array}$ & $\begin{array}{c}\text { collected in } \\
\text { milk-collected } \\
\text { units }{ }^{2}(\mathrm{t})\end{array}$ & $\begin{array}{c}\text { Total } \\
\text { number }\end{array}$ & $\begin{array}{c}\text { Physical } \\
\text { persons }\end{array}$ & $\begin{array}{c}\text { Sole } \\
\text { proprietors }\end{array}$ & $\begin{array}{c}\text { Trade } \\
\text { companies }\end{array}$ \\
\hline During 2001 & 14190 & 9800 & 12354 & 400 & 3 & 193 & 204 \\
During 2000 & 15677 & 20747 & 838 & 445 & 4 & 221 & 220 \\
\hline
\end{tabular}

Source: Agro-statistical Department 2001, 2002

Table 9. General characteristics and meat production in slaughterhouses

\begin{tabular}{|c|c|c|c|c|c|c|c|c|}
\hline \multirow{2}{*}{$\begin{array}{c}\text { General } \\
\text { structure of } \\
\text { slaughterhou } \\
\text { ses }\end{array}$} & \multicolumn{2}{|c|}{$\begin{array}{c}\text { Slaughterhouses for } \\
\text { lambs }\end{array}$} & \multicolumn{2}{|c|}{$\begin{array}{l}\text { Slaughterhouses for } \\
\text { other sheep }\end{array}$} & \multicolumn{4}{|c|}{ Ownership of slaughterhouses } \\
\hline & Number & $\begin{array}{l}\text { Number of } \\
\text { slaughtered } \\
\text { lambs }\end{array}$ & Number & $\begin{array}{l}\text { Number of } \\
\text { slaughtered } \\
\text { sheep }\end{array}$ & $\begin{array}{c}\text { Total } \\
\text { number }\end{array}$ & $\begin{array}{l}\text { Physical } \\
\text { persons }\end{array}$ & $\begin{array}{c}\text { Sole } \\
\text { proprietors }\end{array}$ & $\begin{array}{c}\text { Trade } \\
\text { companies }\end{array}$ \\
\hline During 2001 & 82 & 586000 & 67 & 7900 & 209 & 0 & 95 & 114 \\
\hline During 2000 & 113 & 561400 & 75 & 7610 & 274 & 7 & 129 & 137 \\
\hline
\end{tabular}

Source: Agro-statistical Department 2001, 2002

gaining group.

The figures show decreasing in dairy enterprise number (2001/2000 year), which can be attributed to procedures of regulation within this realm supposing approximation to EU criteria. But more interesting is that there is tangible discrepancy between 2001 and 2000 about milk purchased directly and sheep milk collected in milk-collected units. During 2001 is ascertained great increasing of indirect collected sheep milk, as a result probably of detachment between enterprises and producers and focusing on impersonal relations.

The number of milk and meat manufacturers concerns merely those enterprises that are registered as throughout country run a lot of entities that don't have license for such activity. There are two factors, exuberance of manufacturers (mostly dairy ones since purchasing of sheep is depended at greater extent from export) and shrunk market of sheep milky products, which push the manufacturers to seek cost reduction. Unfortunately, it is fulfilled mostly through truncating purchasing farmers price.

\section{DIMENSIONS OF CRUCIAL FACTORS INFLUENCE}

\section{Relations with manufacturers and middlemen}

The relation between particular agents in trade off process is very complicated. Recently, many scholars point out the asymmetric information as an immanent factor in interrelation process. Asymmetric information is the basic concept outlines properties of stronger side (agent) in dealing process to enjoy some information advantages over the principal (weaker side). The sheep farmers can be represented as principals since they 
are chief producers of commodities, which are subject of trade, while manufacturers and middlemen are the motor of these processes. In fact, the sheep farmers are stationed down under inclement circumstances in terms of their market awareness. For instance, nowadays farmers are harassed by a lot of "anonymous" purchasers, who suggest to farmers a good price for their products, purchased their products as in the end do not meet their payment duties (moral hazard).

This post-dealing asymmetric problem is due to scarce information about reputation of different firms that are involved in these relations. Besides, the middlemen very often have preliminary information mostly for price movements and avail by instantaneous dealing on expense of short-informed farmers. The most afflicted farmers from asymmetric matter are small sheep ones that arduously find out the actual information in comparison with bigger ones. Aftermath of such conditions is restraint of sheep farmers to venture before to ensure against such loses. Naturally, there is opposite asymmetric matter devoted to sale situation whenever the farmers know more about a thing than sellers. The banal example of such kind is overt perpetration by some farmers to slender sheep milk on purpose to enlarge quantity or to add illicit ingredients so as to be risen the fat

Table 10. Destination of sheep milk production

\begin{tabular}{|c|c|c|c|c|c|c|c|}
\hline $\begin{array}{l}\text { Farm classes } \\
\text { and } \\
\text { destination }\end{array}$ & $\begin{array}{l}\text { Sample of } \\
\text { field-survey } \\
\text { '02 number }\end{array}$ & $\begin{array}{c}\text { Average } \\
\text { sheep } \\
\text { number }\end{array}$ & $\begin{array}{c}\text { Total milk } \\
\text { production } \\
\text { in surveyed } \\
\text { farms/l. }\end{array}$ & $\begin{array}{l}\text { Average } \\
\text { milk } \\
\text { production } \\
\text { /iters }\end{array}$ & $\begin{array}{c}\text { Total quality of } \\
\text { self-sufficiency } \\
\Lambda .\end{array}$ & $\begin{array}{c}\text { Total sale } \\
\text { without } \\
\text { contract } / .\end{array}$ & $\begin{array}{l}\text { Milk peddles } \\
\text { as } \\
\text { homemade } \\
\text { products } / \text {. }\end{array}$ \\
\hline $\begin{array}{l}\text { Large-scale over } \\
101 \text { sheep }\end{array}$ & 5 & 217.6 & 49930 & 9986 & 6292 & 39969 & 3669 \\
\hline $\begin{array}{l}\text { Medium -scale } \\
51-100 \text { sheep }\end{array}$ & 7 & 63 & 22635 & 3334 & 3870 & 16765 & 2000 \\
\hline $\begin{array}{l}\text { Small-scale } \\
21-50 \text { sheep }\end{array}$ & 10 & 30.9 & 17853 & 1785 & 6180 & 10873 & 800 \\
\hline $\begin{array}{l}\text { Nominal farms } \\
\text { up to } 20 \text { sheep }\end{array}$ & 25 & 9.8 & 9914 & 397 & 6368 & 1798 & 1748 \\
\hline
\end{tabular}

Source: Survey data, 2002

Table 11. Correlation in milk production regarding farm class opportunity

\begin{tabular}{|c|c|c|c|c|}
\hline $\begin{array}{l}\text { Correlation in milk } \\
\text { production }\end{array}$ & $\begin{array}{c}\text { Sheep } \\
\text { Number/Total } \\
\text { production }\end{array}$ & $\begin{array}{c}\text { Total } \\
\text { production/self- } \\
\text { sufficiency }\end{array}$ & $\begin{array}{c}\text { Total } \\
\text { production/ } \\
\text { sale without } \\
\text { contract }\end{array}$ & $\begin{array}{c}\text { Total } \\
\text { production/ } \\
\text { peddling sale }\end{array}$ \\
\hline Coefficients of correlation $r$ & 0.97 & 0.62 & 0.97 & 0.92 \\
\hline Coefficients of determination $r^{2}$ & 0.94 & 0.37 & 0.94 & 0.83 \\
\hline $\begin{array}{l}\text { Tests of significance } 5 \text { per cent, } \\
t \text { is } 2.021\end{array}$ & it, 26 & 5.25 & 26 & 14.69 \\
\hline
\end{tabular}

Source: Survey data, 2002 
index, which is tallied up under compound pricing.

The figures distinctly show breakdown between farmers and dairy enterprises. The sale of milk is around $70 \%$, as the most troublesome fact is that great percentage of those sales, are implemented by peddling (over all farms $8 \%$ ). This percent varies as for nominal sheep farms proportion between sale milk to dairy enterprise and itself processing of sheep milk to some kind of products (mostly cheese) or fresh milk peddling to mostly known people is fifty-fifty.

There has been seen that percentage of peddling milk in large-scale farms is also impressive which can be due to inability of some of those farms to grip satisfied price of their production and their turn to peddling way. The test of significance of various correlation pairs portrays significance of upper relationships as the lowest relationship exists between total production of sheep milk and self-sufficiency (0.62). The total production of sheep milk is in close relation with size of farms thus self-sufficiency doesn't depend so strong from size of farm comparatively with other relationship (sheep number-total production 0.97 and total production-sale without contract 0.97 ). It is true that almost all of below subset farms of nominal class design their production almost entirely for intermediate consumption but it is rarely to meet bigger farms that have relatively high self-sufficiency percent. The high percent of self-sufficiency within those farms can be imputed to inability of those farms to find satisfied demand and price of milk.

The self-sufficiency relates very close with utilitarian principle, which is one of intellectual landmarks of the last two centuries. The notion of utility arose soon after 1700 among students of mathematical probability. Later, William Jevons (1835-1882) extended Bentham's utility concept to explain consumer behavior. Besides, the law of diminishing utility postulates that the amount of extra or marginal utility declines as a person consumes more and more of a good. Since, in Bulgarian economy now is reigning the law of demand and supply as well as competition is driving factor for their determination thus farmers by self-sufficiency see way to place their products and to reliance on self-hiring.

In ideal case, sheep farmers prefer to achieve maximum sale level of milk over cash terms but because of technological conditions (purchasing time by dairy enterprises and sheep lactation time do not concur ultimately) and economic conditions (inadequate price and poor demand) they can not. The graph illustrates the effect of self-sufficiency in

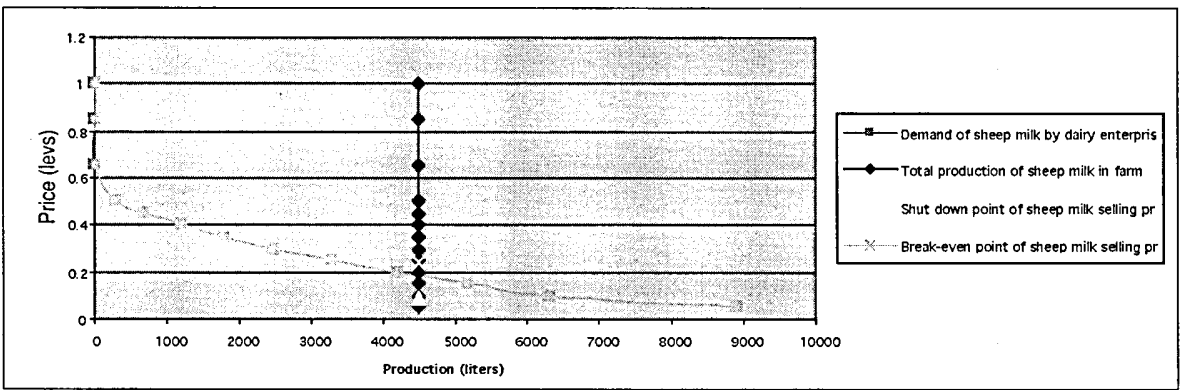

Source: Survey data, 2002

Fig. 2. Demand and production of sheep milk by prices under $6.5 \%$ fat units 
a random selected farm. The goal of this graph is to be made attempt to ascertain the utility value of self-sufficiency following the chief paradigm in economics - maximization of profit and utility. However, most of farmers (mostly nominal, small and medium size) have as a final goal the high level of living and maximum satisfaction for their family, which is assumed not to controvert to main standpoint of maximization. Therefore, from study point of view is interesting to be aware the value of self-sufficiency by farmers in order to be predicted that either self-sufficiency has high value by sheep farmers or that self-sufficiency is sequence of poor demand of sheep products and low earning of farmers.

The average number of dairy sheep, which can allow achieving this total production of milk is about $50-70$ heads. This example is picked because on one hand in case of relatively bigger production of sheep milk can be observed "dichotomy choice" between self-sufficiency and market sale from farmers, on the other hand at this quantity of produced sheep milk can be spoken for a sustainable farm. Abreast with it, in Bulgaria are claimed gradually increasing of sheep number and progressive growth of sheep raised in middle and large-scale farms. In the plot are indicated various categories, which meaning must be explained. Total production of sheep milk is considered to be constant (4500 liters), inasmuch in short-run, the farmers can not deal with price changes and their supply curve is strongly inelastic to demand. The demand curve is extrapolated conceding some main conditions:

- within this market exists competition, which does not brook gravely distortion in milk price

- the starting price, which dairy enterprises can offer to farmers can not be more that selling consumer price of sheep products

- dairy enterprises stand by for purchasing the whole production of milk (4500 liters) at price about $\$ 0.17$ through purchasing sheep milk as cow milk because at the beginning and in the end of sheep lactation the quality and the quantity of sheep milk are lowered and enterprises just mix sheep and cow milk in processing

Table 12. Kind of involved costs by sheep and per liter milk

\begin{tabular}{lccc}
\hline $\begin{array}{l}\text { Kind of involved costs } \\
\text { by sheep and per liter } \\
\text { milk }\end{array}$ & $\begin{array}{c}\text { Variable cash costs per } \\
\text { sheep including feed, } \\
\text { medicines, maintenance, } \\
\text { etc } \$\end{array}$ & $\begin{array}{c}\text { Implicit costs } \\
\text { incurred for } \\
\text { sheep keeping } \\
\text { labor per year } \$\end{array}$ & $\begin{array}{c}\text { Implicit costs incurred for fixed } \\
\text { machine and labor costs } \\
\text { embodied in sheep connected } \\
\text { activities } \$\end{array}$ \\
\hline $\begin{array}{l}\text { Average cost per sheep } \\
\begin{array}{l}\text { Calculation average } \\
\text { costs per liter milk }\end{array}\end{array}$ & 16.5 & 19.5 & 8.05 \\
\hline
\end{tabular}

Source: Survey data, 2002

The farm case, which is selected, is much common for Bulgarian sheep husbandry reality as cost elements are divided to three particular realms. The variable cash costs are calculated taking into account feed costs (grain, industrial, mineral and roughage) consisted of all costs necessitate to produce, harvest and to forward this production. In this item are not involved sundry implicit costs. These costs are calculated within farm 
where $\%$ of self-feed procurement is high while about other farms that purchase some part of their forages, these costs would be higher. On the other hand variable cash costs can be reckoned as equivalent of shut down point of selling sheep milk, since these are costs that are directly bound to production itself. Implicit costs incurred for sheep keeping labor are obtained on average present salary in Bulgaria. In the literature concerning labor in sheep husbandry, labor norms are worked out, as a shepherd must keep about 80 dairy sheep. The implicit costs concerning fixed machine and labor expenses involve proportional cost value of machines in sheep enterprise as well as labor expenses.

\section{Estimation of self-sufficiency in sheep enterprise}

Regarding to estimation of self-sufficiency is necessary to be elucidated all question marks in Figure 1. In Field-Survey'02 was found out that average obtained milk apart from sucking milk from lambs over 1 lactation is 65 liters. Besides, the revenue pattern shows that over 2002, the share of milk revenues within total production revenues make up $37 \%$, as within this calculation was excluded costs for sheep raising over no fertility stage presuming that these expenditures must be equal of proceeds gotten at selling of those sheep. Thus on the figure are portrayed shut down and break-even points, which are derived from cost pattern in the farm. Shut down point of selling sheep milk price is assumed to concur with variable cash costs for feed, medicines, etc. These are explicit production cash costs that farmers necessitate to get back as minimal warranty for no explicit losing profile of production. Break-even point stands for those costs that have relation to sheep enterprise but that are implicit for farmers. As a result of short of money, which sheep farmers go through under a free market economy, they are eager to reduce explicit costs by overhead (implicit) costs. Altogether, farmers are prone to keep on their engagement in sheep enterprise beneath break-even point of revenue feasibility but they will never tolerate durable running under shut down level of their revenues.

Proceeding from proposition that farmers pursue maximization of their utilization as well as their rational motives becomes possible to educe that value of self-sufficiency utility would never be less than consented selling price to dairy enterprises. In the above example, the farm launches to sell its sheep milk on $\$ 0.22$, where it supplies about 3800 liters. Remnant from $700 \mathrm{l}$. is utilized as self-sufficiency and deducing from value of self-sufficiency preposition can be enunciated that the value of self-sufficiency of this 700 l. is equal of $\$ 0.22$ (selling price to dairy enterprise). The triangle, which can be depicted between price $\$ 0.22$, quantity of sold milk to dairy enterprise 3800 liters and the highest self-sufficiency value of remnant sheep milk stands for "extra value", which farmers get from self-sufficiency. This "extra value", which farmers are able to merit from self-sufficiency overreaches the ordinary selling price of sheep milk as well as offsets at some extent the gap between real cash price and price at break-even point plus normal profit for farmer activity.

As for other staple product in sheep enterprise - lambs, situation with self-sufficiency is pretty more different. First, the lamb revenues account for $59 \%$ of gross revenues in sheep enterprise. This product probably is only advantage within sheep farming, which demand keep stable through time. The price of lambs also floats in comparatively stable levels as on reliance of good price and demand, which prevents sheep enterprise from more terrible slump. That is why, while under milk production, self-sufficiency features 
Table 13. Kind of involved costs by sheep and lambs

\begin{tabular}{cccc}
\hline $\begin{array}{c}\text { Kind of involved } \\
\text { costs by sheep and } \\
\text { lambs }\end{array}$ & $\begin{array}{c}\text { Variable cash costs per } \\
\text { sheep and lamb including } \\
\text { feed, medicines, } \\
\text { maintenance, etc } \$\end{array}$ & $\begin{array}{c}\text { Implicit costs } \\
\text { incurred for sheep } \\
\text { and lamb keeping } \\
\text { labor per year } \$\end{array}$ & $\begin{array}{c}\text { Implicit costs incurred for fixed } \\
\text { machine and labor costs } \\
\text { embodied in sheep connected } \\
\text { activities } \$\end{array}$ \\
\hline $\begin{array}{c}\text { Lamb concerning costs as } \\
\text { part of total costs for } \\
\text { sheep keeping per kg live } \\
\text { weight }\end{array}$ & 0.43 & 0.51 & 0.21 \\
$\begin{array}{l}\text { Costs belong to lamb } \\
\text { keeping per kg live weight }\end{array}$ & 0.18 & - & 0.08 \\
$\begin{array}{c}\text { Total costs lean to lambs } \\
\text { per kg live weight }\end{array}$ & 0.61 & 0.51 & 0.29 \\
\hline
\end{tabular}

Source: Survey data, 2002

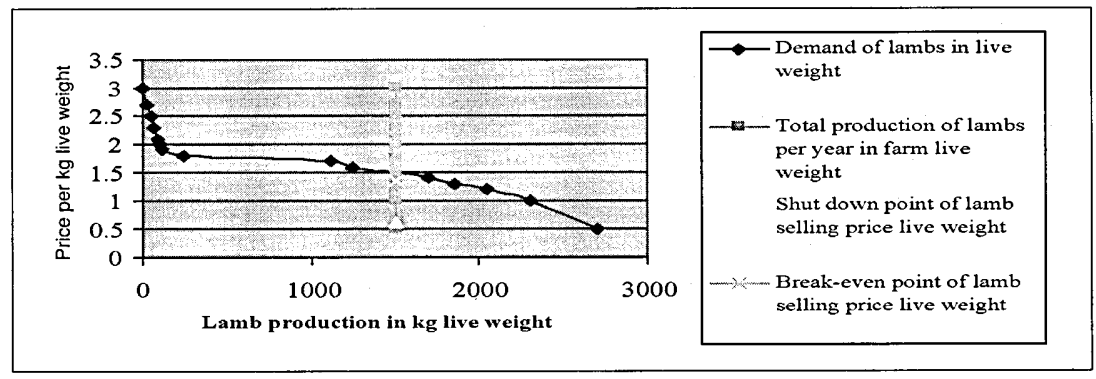

Source: Survey data, 2002

Fig. 3. Production and demand curves together with extrapolated different cost levels

with reluctance to some extent against low purchasing price of sheep milk, under lambs, self-sufficiency must be thought by different way.

The relatively good demand and price of lambs bring self-sufficiency with this product to minimal levels of it and to relatively high utility value of self-sufficiency. Opportunity costs of self-sufficiency in lamb production are quite high, hence, utility value of self-sufficiency is constrained and sheep farmers do not score special merit to hold high percentage of lamb intermediate consumption. Likewise extrapolation of shut down and break-even points in sheep milk production, in lamb production also is employed the same model.

The above graph demonstrates rather different situation of lamb production opportunity in comparison with milk one. The price levels are fairly auspicious as the price from $\$ 1.5$ per $\mathrm{kg}$ live weight conveys to farmers a good economic rent about $\$ 0.15$ per $\mathrm{kg}$ in example farm. Therefore most of sheep farmers avail by good price of lambs, as get through to compensate a big part of inefficient milk production. However, it refers to upper classes of sheep farms, while nominal sheep farms (up to 20 heads) yet do not have enough cash inflow to meet their cash expenditures. In consequence of character of lamb 
production is likely the farmers to conduct differential price selling. It means that they are able to sell at different price their lamb production regarding to customers. It allows them to grab economic rent (difference between attainted selling price and equilibrium price between demand and farm supply). The shape of demand curves can be divided to 2 sectors. The first sector encompasses beginning of demand curve discerned by steeply slope as consequence of individual demand (retail demand). The farmers take advantage from higher price (around \$1,9live weight) of individual sale ignoring intermediate position of market channels and clutch their intermediate profit. Therefore they can adjust with demand at selling price different from premier achieved equilibrium.

\section{CONCLUSIONS}

Altogether, farmers face such "critical factors" that at great extent predetermine state of those farms. Study of these factors allows to be found out reasons and specifics, which exist in sheep enterprise, as well as to be outlined differences between various size and type farms. The analysis of internal environment in sheep farms portrays inability of sheep farmers to adjust to a sustainable state for producing on the frontiers of production optimum as well as for a lot of unsolved issues devoted to the management, production system within those farms, the modes for husbandry, etc. As long as this pattern with $90 \%$ nominal farms (up to 20 heads) prevails in sheep farming model of Bulgaria so long will continue miserable being of people engaged in it and will testify for problems there. The nominal sheep farms can't adopt new requisitions for advanced sheep husbandry (renovation of breeding structure and application of new management know-how) on account of their nature of temporary entities aim to help their livelihood, not to invent and develop their farms. The most of farmers should find more rational decisions about summer grazing of flocks. They should try to group their flocks supposing 1 shepherd during grazing span to be in charge of minimum 100 heads. That is why is necessary diversification in sheep farms to yield on behalf of concentration in them.

Besides, it was traversed significance of two concepts (bounded rationality and opportunism) out of pure economics but immanent part of social relationships to which business relations belong. Therefore, the market represents a discrete mechanism, which can be propelled in directions favoring particular minor group on cost of majority. Appearing of old-mode forms of distribution (peddling) as well as high percentage of self-sufficiency can be imputed as sequence of subdued stand of sheep farmers juxtaposed with dairy companies and middlemen. Self-sufficiency, especially in large and medium size farms by this analysis can be explicated as reluctance against low purchasing prices. This reluctance stands for seeking some utility value of remaining production (out of sold and those designed for intermediate consumption), which is hard and brings about lower return of it. Since, the reluctance is an irrational behavior, the farmers who carry out such strategy can not withstand for long time and they must truncate size of farms in case that situation does not change, thereby external factors have direction impact on size of particular farms.

\section{REFERENCES}

Heady E. and Jensen H. 1954 Farm management economics. Prentice Hall, INC, New York 
Faur R. 1967 Sheep farming for profit. A. H and A. W. Reed

Heady E., Johnson G., Hardin L. 1954 Resourse productivity, returns to scale and farm size. College Press, Iowa State

Hall R., Hitch C. 1965 Price theory and business behaviour. Oxford Economic Paper., 2 Thracian

University. Proceeding on livestock issues in Republic of Bulgaria. Plenary Report., 1.1 (in Bulgarian)

Williamson O., 1985 The Ecomic Institutions of Capitalism. New York, Free Press

Simon H., 1957 Models of Men. New York, wiley

Coase R., 1988 The Firm, the Market and the Law. Chicago and London, University of Chicago Press

Tyankov S., Dimitrov I., and Co. 2002 Sheep and goat husbandry. In "Proceeding on livestock issues in Republic of Bulgaria-Manual Report Book", Vol. 2, ed. by Stara Zagora, Silve, pp. 56-76 (in Bulgarian)

Koychev K. Effectiveness of sheep production. 1983 Report, Sofia, Institute of Agricultural Economics. (in Bulgarian)

Yovcheva M. 1976 Factors for increasing intensification level in sheep husbandry. Report, Sofia, Institute of Agricultural Economics. (in Bulgarian) 